\title{
Adopting Multiactor Multicriteria Analysis for the Evaluation of Energy Scenarios
}

\author{
Sebastian Schär *Did and Jutta Geldermann \\ Chair of Business Administration and Production Management, University of Duisburg-Essen, 47057 Duisburg, \\ Germany; jutta.geldermann@uni-due.de \\ * Correspondence: sebastian.schaer@uni-due.de
}

Citation: Schär, S.; Geldermann, J. Adopting Multiactor Multicriteria Analysis for the Evaluation of Energy Scenarios. Sustainability 2021, 13, 2594. https://doi.org/doi:10.3390/ su13052594

Academic Editor: Thomas Pregger

Received: 2 February 2021

Accepted: 24 February 2021

Published: 1 March 2021

Publisher's Note: MDPI stays neutral with regard to jurisdictional claims in published maps and institutional affiliations.

Copyright: (c) 2021 by the authors. Licensee MDPI, Basel, Switzerland. This article is an open access article distributed under the terms and conditions of the Creative Commons Attribution (CC BY) license (https:/ / creativecommons.org/licenses/by/ $4.0 /)$.

\begin{abstract}
The assessment of future options and pathways for sustainable energy systems requires considering multiple techno-economic, ecological and social issues. Multicriteria analysis methods, which are useful tools that aid decision processes involving various and even conflicting qualitative and quantitative criteria, could support such comprehensive analyses. With regard to energy policies, the key actors and stakeholders' acceptance of emerging and innovative technologies for generating, converting and storing electricity, heat and fuels is crucial for their future implementation. The multiactor multicriteria (MAMCA) methodology was developed to involve stakeholders with vastly different views and objectives when addressing complex societal problems. We extend the MAMCA methodology to include the outranking approach PROMETHEE, which allows us to explicitly consider the stakeholders' objectives in the evaluation process. The MAMCA method with PROMETHEE is applied to a case study of four different transition pathways of providing electricity to a bioenergy village in Germany. The explicit mapping at hand of an illustrative case study could help researchers and decision makers greatly in the assessment of pathways for sustainable energy systems; it is also applicable in other contexts requiring extensive stakeholder involvement and where qualitative and quantitative criteria are to be considered simultaneously. The detailed sensitivity analysis provided by the extension of the MAMCA method with PROMETHEE not only reveals the stakeholders' crucial trade-offs when allowing each stakeholder group to develop its own set of criteria and weights but also indicates compromise options.
\end{abstract}

Keywords: energy scenarios; energy technology assessment; multicriteria analysis; stakeholder involvement; multiactor multicriteria

\section{Introduction}

The transition from the current electricity system to a renewable electricity supply poses immense economic, technological and policy challenges [1,2]. Within this process towards a more sustainable energy system, energy scenarios can be a valuable instrument [3]. Energy scenarios are representations of possible development paths towards desired future energy system states, in order to provide guidance for decisions associated with the transition process $[4,5]$.

Allowing citizens and companies to invest in renewable energy and thereby become independent power producers has not only advanced the population's acceptance of renewable energy but has also accelerated the move towards a more decentralised and sustainable power supply [6,7]. Consequently, energy policies need to take divergent groups of key actors and stakeholders' viewpoints into account. In turn, when transforming an energy system, policy-makers need to take multiple, often conflicting, criteria and stakeholder interests into account in order to identify, evaluate and, ultimately, implement possible development paths [8].

Multicriteria analysis's (MCA) methods have been used to support decision processes involving energy scenarios and to explicitly allow for conflicting criteria (e.g., investments 
or emissions) [9-11]. In this context, these methods offer the possibility of evaluating several energy scenarios and considering path dependencies [3] but without explicitly taking different stakeholder objectives into account. See [8] for a recent overview of studies applying MCA to evaluate energy scenarios.

Without stakeholder acceptance, emerging and innovative technologies' smooth implementation to generate, convert and store electricity, heat and fuels may be unlikely [11]. Recent public reactions to projects related to energy supply have highlighted the importance of the public's acceptance of energy policy measures to ensure they support realised projects [12].

Against this background, this paper makes a twofold contribution. First, we present an exemplary application of a decision analysis method that allows the decision maker to be fully aware of the stakeholders' objectives and reveals the strengths and weaknesses of alternatives. We do so by building upon the multiactor multicriteria (MAMCA) method, which Macharis et al. [13] developed and use an illustrative case study to highlight the benefits of methodologically integrating stakeholders into energy scenario planning. The MAMCA method clarifies the alternatives' essential trade-offs by allowing each stakeholder group to develop its own set of criteria and weights. Furthermore, we extend existing work by using the PROMETHEE method to explicate the aggregation procedure. The framework presented in this work supports decision makers in energy system planning; it is also applicable in other contexts requiring extensive stakeholder involvement.

The remainder of the paper is structured as follows. In Section 2, we define the stakeholder concept in general and in the context of energy policy decisions. In Section 3, we present the MAMCA method and highlight how it differs from multicriteria analysis methods. In Section 4, we demonstrate how the MAMCA method can be applied in energy scenario planning in a case study on planning a power generation system based on renewable resources in a German village. The major contributions and findings are summarised in Section 5. In addition, we discuss the implications of our research and the opportunities for further research.

\section{Stakeholder Involvement in Energy Scenario Decision Processes}

When designing an energy scenario, an important precondition for smooth realisation is to ensure the stakeholder's acceptance. Active opposition of stakeholders to projects during the planning and, especially, the actual implementation phase can lead to delays or even the failure of an otherwise promising project's realisation. In the energy decision context, we define stakeholders as everyone who is or feels affected by a decision, therefore feeling that their values and perceptions should be taken into account [14]. A modern phenomenon is for a majority of the population to view certain developments, such as the transition to an energy system with a higher share of renewable sources, positively. However, these same people change their minds once specific projects confront and affect them [15]. The scientific literature has already discussed active opposition to siting decisions, which is primarily expressed at the local level. For examples, see the works of Bell et al. [16], Jobert et al. [17] or more recent articles by Bertsch and Wolf [11], Guo et al. [18] and Gonyo et al. [19]. In this section, we address this issue in terms of energy scenarios and discuss approaches that decision makers could use to methodically engage with stakeholder groups in order to prevent active opposition and facilitate the acceptance of decisions.

\subsection{Role of Stakeholders in Energy System Design}

In order to develop suitable methods for better stakeholder involvement in the design and implementation of energy scenarios, decision makers should first and foremost understand the reasons for active stakeholder opposition. Although surveys confirm that the general public views renewable energy technologies positively, concrete projects are often subject to controversy [20]. This is especially true in the wind energy context, in which the perceived noise and visual impact are cited as reasons for stakeholders' rejection [21]. 
The literature often refers to this behaviour as the not in my backyard (NIMBY) effect [22]. However, this acronym's use has become contentious: there is no widely accepted, clear definition of the acronym, nor is what nimbyism constitutes exactly fully explained as yet $[16,23,24]$. The proximity hypothesis, which implies an increase in negative attitudes when residents' spatial distance to a planned wind turbine site decreases, still lacks empirical evidence [18]. However, some scholars mention that residents have a positive attitude to energy projects in close proximity to them, due to the associated increase in their income through financial participation $[25,26]$, but this may depend on the actual mode of inclusion and may vary for different population groups [27]. Warren et al. [28] and Devine-Wright [29] provide further empirical evidence supporting the hypothesis that local residents' attitudes to wind farms actually become more positive after construction, therefore refuting the proximity hypothesis in general. Finally, there is growing consensus within the scientific literature that the phenomenon is more complex than initially thought and that the reasons for local opposition to renewable energy projects are far more varied and beyond simple self-interest or the rejection of a specific technology $[15,30]$. Rather, the specific stakeholder groups' opposition is based on certain values, beliefs, contextual, social and psychological factors [31,32]. By simply categorising all opposing behaviour to energy planning decisions under the broad label of NIMBY, decision makers miss an opportunity to discover stakeholders' actual motivations [33].

However, what exactly are these findings' concrete implications for energy planning decision makers, and how can they address or even prevent stakeholders' opposing behaviours? In debates on the siting of nuclear waste disposal, Kraft and Clary [34] define the term NIMBY as "intense, sometimes emotional, and often adamant local opposition to siting proposals that residents believe in will result in adverse impacts". These beliefs are mainly based on distrust, high concerns about the risks and a limited availability of information, so that the involvement of a broader and more diverse set of experts as well as more citizen participation in decision making may promote stakeholder acceptance [34]. Although the nuclear waste disposal context is not really comparable to the energy planning field, the implications of this case might be transferrable. Van der Horst [15] provides an extensive exploration of how renewable energy facilities' siting decisions shape individual attitudes, particularly with regard to wind turbines. He concludes that the main reason for opposing behaviour is the lack of an opportunity to interact and collaborate, which "allows people to oppose proposed projects without the inconvenience of having to think or decide where or how else the underlying social objectives [... ] could be better achieved".

Wolsink [22] further argues that strong public support for certain energy technologies alone does not suffice but rather has to be accompanied by more open and collaborative decision processes instead of top-down planning. Bell [16] highlights that involving stakeholders throughout the entire decision making process from the onset may reduce the risk of opposition upon realisation, since stakeholders are more likely to feel as decision makers themselves and are offered sufficient opportunity to express their objectives and concerns. He advises that instead of using an "announce and defend" strategy once the final decision has already been made, decision makers should use a strategy that provides stakeholders with a forum to voice their concerns and, if possible, should include them in the decision making process [35].

Consequently, we examine the available decision making methods that allow active stakeholder involvement throughout the decision process with emphasis on applications within the energy scenario planning context.

\subsection{Evolution of Methods for the Evaluation of Energy Scenarios}

Stakeholders should not to be regarded as a homogeneous group, since they often differ considerably regarding their goals, opinions and perceptions [14]. The use of multicriteria analysis (MCA) methods has become increasingly popular to achieve consensus and balance interests despite conflicting goals [36-40]. Especially for the assessment of renewable technologies, MCA methods have been applied extensively in recent years, as 
the reviews by Rigo et al. [41] and Siksnelyte-Butkiene [42] highlight. The application of MCA allows for integrating the values of stakeholders across the different phases of the planning process by collecting, structuring and analysing the related information [43]. At best, the collaborative approach promotes learning effects among stakeholders [38] and reveals aspects and alternatives that decision makers might have previously overlooked [44]. However, a decision maker should decide on the method's exact design, how to define the stakeholders' scope and how to ultimately incorporate the stakeholders' values and opinions in the analysis [43]. After all, the quality of results not only depends on the choice of a suitable method but also on applying it in a way that will solve the problem. Moreover, the explicit involvement of stakeholders in the decision making process should not deter decision makers from questioning their inputs critically [45].

Huang et al. [46] provide an in-depth review of MCA applications in the context of environmental decision making projects. The authors report a significant growth in MCA applications at the beginning of the 21st century but distinguish between energy context applications and those contexts that explicitly require stakeholder involvement. A comprehensive overview of stakeholders' methodological integration into MCA can be found in Marttunen et al. [43]. In a recent work, Höfer and Madlener [8] developed a multicriteria group decision model based on Keeney's value-focused thinking [47] to construct a holistic objective system and develop the multiattribute utility theory (MAUT) in order to evaluate energy transition scenarios.

In order to characterise and cluster stakeholders, French and Geldermann [14] suggest using different stakeholder stereotypes for decision making, since each has distinctive risk attitudes, perceptions and values. Designing decision processes in such a way that they address the full range of stakeholder perceptions and values should therefore be advantageous. In the context of energy scenario evaluation, Steinhilber et al. [48] provide a framework in line with this idea. The authors characterise different stakeholder prototypes to identify possible conflicts and potentials for compromise by analysing different renewable energy policy pathways in the EU on the basis of PROMETHEE. The findings indicate that, while all stakeholders seem to share the common objective of the long-term decarbonisation of the economy, there is no consensus on the criteria and choice of alternatives.

\section{The Multiactor Multicriteria Analysis Method}

In this section, we describe how the MAMCA method allows for the explicit consideration of stakeholders' objectives. Figure 1 illustrates the MAMCA methodology, according to Macharis et al. [49], which follows the general procedure of MCA methods [14,50] and is conducted in seven steps. Since the findings from one step may yield new insights for a previous step, the methodology has an iterative character. To provide an example, the analysis of the stakeholders' goals, values and perceptions in the second step or the determination of decision-relevant criteria in step three could lead to the identification of previously neglected or unconsidered alternatives. In turn, the set of alternatives is updated and it may be required to gather opinions of all relevant stakeholders for the updated set of alternatives. 


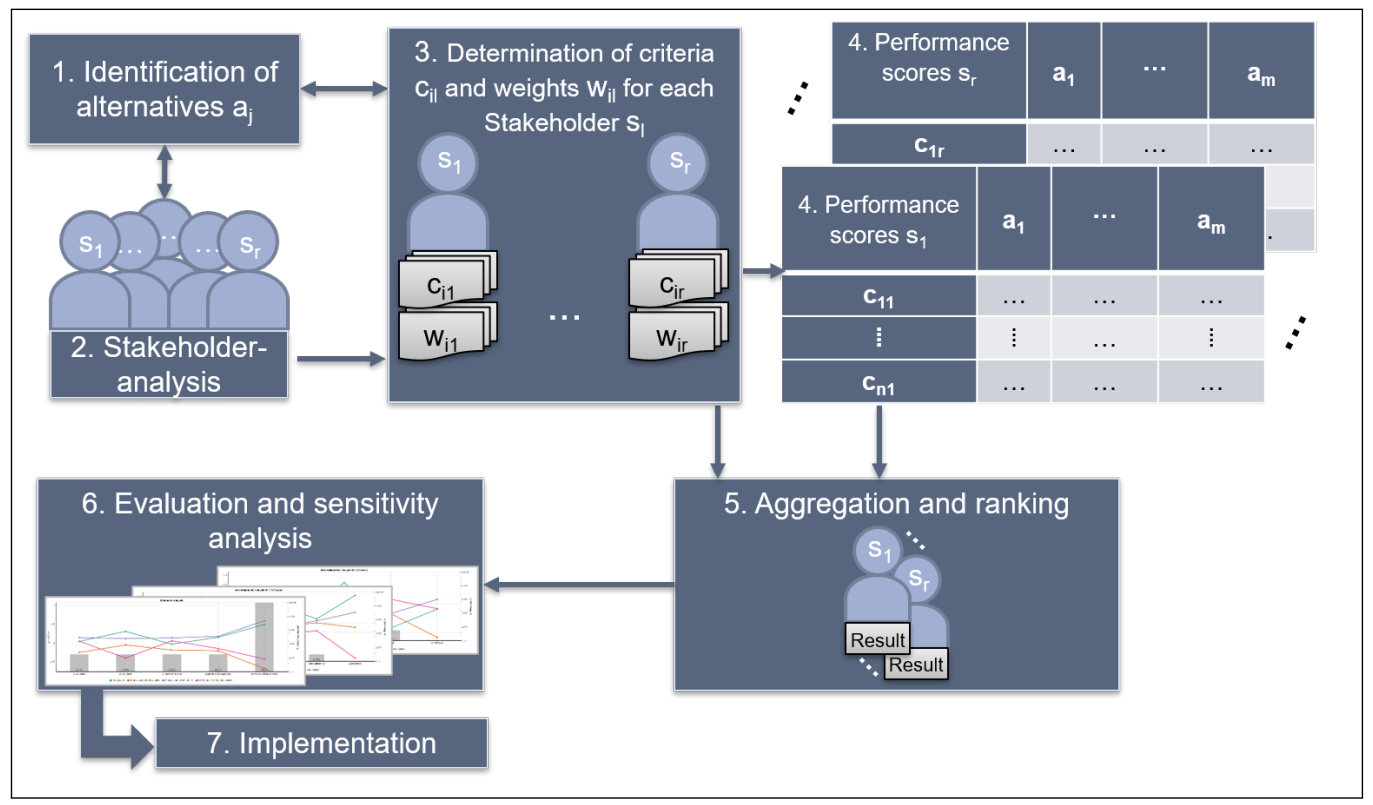

Figure 1. The MAMCA methodology according to Macharis et al. [49]. The seven steps are not to be considered sequential, but iterative, since the findings from one step may yield new insights for a previous phase. To explicitly consider different stakeholders within the analysis, each stakeholder is granted a separate set of criteria according to which the alternatives' performances are to be assessed. The resulting performance matrices and the corresponding criteria weightings of all stakeholders are then aggregated and evaluated. Since data is collected specifically for each stakeholder, a more comprehensive sensitivity analysis is possible.

\section{Step 1: Identification of alternatives}

The first step within the MAMCA methodology consists of identifying and defining the decision problem by means of classifying the set of possible alternatives $a_{j} \in$ $A=\left\{a_{1}, a_{2}, \ldots, a_{m}\right\}$ to be evaluated [49]. Designing the alternatives and their features depends on the underlying problem context. Alternatives can, for instance, take the form of technological solutions, possible future scenarios or policy measures [51].

Step 2: Stakeholder analysis

After defining the problem context and a set of alternatives, the stakeholders $s_{l} \in$ $S=\left\{s_{1}, s_{2}, \ldots, s_{r}\right\}$ are identified (see Section 2). In order to evaluate the alternatives appropriately, an in-depth understanding of each stakeholder's or stakeholder group's inherent objectives is very important. The stakeholder analysis is a crucial step to properly capture the decision problem and the range of stakeholders to be included in the decision process. This analysis may yield new insights into additional alternatives to include in the overall analysis and therefore triggers a feedback-loop to the previous step [49].

Step 3: Determination of criteria and weights

The stakeholders involved develop relevant criteria, so that, ultimately, each stakeholder group has an own set of criteria. However, each stakeholder group's objectives are first elicited. Based on the objectives, it is possible to identify each stakeholder's relevant set of evaluation criteria with $c_{i l} \in C_{l}=\left\{c_{1 l}, c_{2 l}, \ldots, c_{n l}\right\}$. A distinctive feature of the MAMCA methodology is that the criteria represent the stakeholders' goals and not per se the alternatives' impacts. Furthermore, the stakeholders' goals can vary, which might lead to different criteria applying to the same set of alternatives. Nevertheless, by including all relevant stakeholders in the analysis, the overall set of criteria hierarchies should adequately reflect the alternatives' impacts and effects. If it does not, the range of included stakeholders should be reconsidered to fully capture the decision problem [49]. 
The elicited criteria weights $w_{i l} \in W_{l}=\left\{w_{1 l}, \ldots, w_{n l}\right\}$ express the intercriterial preferences of each stakeholder, whereby the sum of all criteria weights of each stakeholder must, according to Equation (1), be one.

$$
\sum_{i=1}^{n} w_{i l}=1
$$

Decision makers and analysts can utilise any of the available methods, such as SMART, SWING or SIMOS, to obtain each stakeholder's criteria weighting [49,52]. Furthermore, the approach of eliciting criteria and weights on the basis of the stakeholder goals, therefore making their definition subject to the stakeholders' perceptions, solves the well-known problem of criteria interdependency in the MCA methods $[49,53]$.

Step 4: Determination of performance scores

Next, the performance scores $c_{i l}\left(a_{j}\right)=: x_{i j l}$ of each alternative for each stakeholder can be determined with regard to all criteria, ultimately creating one performance matrix for each stakeholder. A performance score is a numerical indicator of an alternative's performance in terms of a single criterion. Using a dedicated attribute for each criterion allows for capturing an alternative's contribution to the stakeholder goals. These dedicated attributes can be quantitative by nature, allowing qualitative data to be quantified by means of ordinal scores. Furthermore, an attribute might measure contributions to more than one criterion [49].

Step 5: Aggregation and ranking

In the fifth step, the information from the previously determined decision tables is aggregated for each stakeholder in order to assess and, ultimately, rank the alternatives. Any of the common MCA methods can be utilised for this aggregation process. It should be noted that Macharis et al. [49] maintain that group decision support methods (GDSM), by means of the preference ranking organisation method for enrichment evaluations (PROMETHEE) [54], the analytical hierarchy process (AHP) [55] and ELECTRE [56], are specifically suitable, because they explicitly allow each of the stakeholders to have separate preference structures, criteria and weight sets.

In this case study, we use the PROMETHEE method developed by Brans [54] to aggregate the results and determine the alternatives' ranking. In the MCA techniques set, PROMETHEE belongs to the category of multiattribute decision making methods (MADM) and utilises the outranking concept by conducting pairwise comparisons between each possible pair of alternatives. The pairwise comparisons of a finite set of alternatives are conducted on the basis of each alternative's performance scores of the considered criteria. As previously mentioned, the set of alternatives is universal to all stakeholders, but each stakeholder group may have a unique set of criteria.

In the first phase, for each stakeholder $s_{l}$, the differences $d_{i l}$ between each criterion's performance scores are calculated according to Equation (2).

$$
d_{i l}\left(a_{j}, a_{k}\right)=x_{i j l}-x_{i k l}
$$

In PROMETHEE, the stakeholders' intracriterial preferences are mapped via six different preference functions (see Appendix A Table A1) [57]. Each criterion is then assigned a preference function $P_{i l}$. Depending on the chosen preference function, the determination of the indifference threshold parameter $q_{i l}$, preference threshold parameter $p_{i l}$ or the inflection point $\sigma_{i l}$ is required. The indifference threshold parameter $q_{i l}$ indicates the largest difference $d_{i l}$ in two alternatives' performance scores from which on a stakeholder is considered to be indifferent. In turn, the preference threshold parameter $p_{i l}$ defines the point from which onward the value of $d_{i l}$ indicates a situation of preference for an alternative. The inflection point $\sigma_{i l}$ of the Type VI preference function is derived from the normal distribution [54]. Using these preference functions and the defined preference parameters, allows, as defined 
in Equation (3), for calculating the resulting unweighted outranking relations of each of the stakeholders.

$$
\pi_{i l}\left(a_{j}, a_{k}\right)=\sum_{i=1}^{n} P_{i l}\left(d_{i l}\left(a_{j}, a_{k}\right)\right)
$$

Based on these outranking relations, an alternative's performance in terms of each criterion is assessed by calculating the unicriterion net flows $[58,59]$ of each stakeholder multiplied by the criteria weighting as in Equation (4).

$$
Y_{i l}\left(a_{j}\right)=\frac{1}{n-1} \sum_{k \in A} \pi_{i l}\left(a_{j}, a_{k}\right) \cdot w_{i l} \quad i=1, \ldots, n
$$

Subsequently, the resulting PROMETHEE net flows of each stakeholder are calculated, as in Equation (5), by summing up the weighted unicriterion net flows of each alternative.

$$
\phi_{l}^{n e t}\left(a_{j}\right)=\sum_{i=1}^{n} Y_{i l}\left(a_{j}\right)
$$

Next, an interstakeholder aggregation is conducted taking, according to Equation (6), the corresponding stakeholder weights $w_{l}^{s} \in W^{s}=\left\{w_{1}^{s}, \ldots, w_{r}^{s}\right\}$ into account, while the sum of all the stakeholder weights should equal one (see Equation (7)).

$$
\begin{gathered}
\phi_{\text {overall }}^{\text {net }}\left(a_{j}\right)=\sum_{l=1}^{r} w_{l}^{s} \cdot \phi_{l}^{\text {net }}\left(a_{j}\right) \quad j=1, \ldots, m \\
\sum_{l=1}^{r} w_{l}^{s}=1
\end{gathered}
$$

In doing so, the issue of eliciting the weights for each stakeholder arises. The literature suggests applying equal weights to the stakeholders in order to express their equal importance and not endanger the MAMCA methodology's overall goal of stakeholder acceptance [49]. Moreover, performing a sensitivity analysis of the stakeholder weighting could yield valuable insights for decision making [58].

Step 6: Evaluation and sensitivity analysis

The last step comprises the evaluation of the previously determined ranking and a thorough sensitivity analysis. A sensitivity analysis within an MCA provides information on the ranking's stability with respect to the applied criteria weights. In MAMCA, the sensitivity analysis is extended even further to the stakeholders' layer.

The crucial part in the MAMCA methodology is the revelation of the critical stakeholders and the relevant critical criteria that provide the decision maker with useful information for the process to reach a consensus among the stakeholders [51]. Critical stakeholders are those stakeholder groups with a substantially different ranking of alternatives than other stakeholders and who, therefore, have a considerable effect on the overall ranking's stability. The criteria of the critical stakeholders which are mainly causing this diverging ranking are referred to as critical criteria. A sensitivity analysis of these criteria might be a promising starting point to facilitate a final decision and a successful implementation. This analysis provides the decision maker with information on what exactly hampers consensus and an assessment of the dissent's magnitude.

Step 7: Implementation

Given the information gained in the previous steps, the seventh step comprises developing implementation paths for the chosen alternative [49]. A promising deployment path could also comprise of an assessment of slightly modified or novel alternatives, depending on the analysis's results. Examining the stakeholder interests closely triggers the creation of feedback-loops that highlight the strong stakeholder focus in all of the MAMCA process's steps. 


\section{Application of the Multiactor Multicriteria Analysis for the Evaluation of Energy Scenarios}

In this section, we present an application of the MAMCA method. The case study aims to illustrate the MAMCA method's functionalities and to highlight this method's distinctive contributions to decisions in the context of energy scenario planning. We do so by examining a bioenergy village in Lower Saxony, Germany $[7,60]$. The village's goal is to transition to a self-sufficient power supply by expanding the capacity of its renewable energy technologies. The village has 1000 inhabitants and an electricity demand of $8021 \mathrm{MWh}$ per year. The target is to satisfy at least $94 \%$ of the electricity requirement (7518 MWh/a) through renewable energy sources. The grid can provide the remaining $6 \%$ (503 MWh/a) required for peak loads. In the following, the MAMCA framework's steps, as presented in Section 3, are applied consecutively.

Step 1: Identification of alternatives

There are three different renewable energy technologies available to this village. To achieve further decarbonisation and increase the village's self-sufficiency, it can utilise solar energy, wind power and biomass fermentation [60]. The photovoltaic (PV) systems can either be built on rooftops or installed as ground-mounted systems.

Based on this information, we define the decision problem's alternatives as the different transition paths' final states which the village should achieve within the 20-year planning horizon. Figure 2 illustrates the relevant configurations.

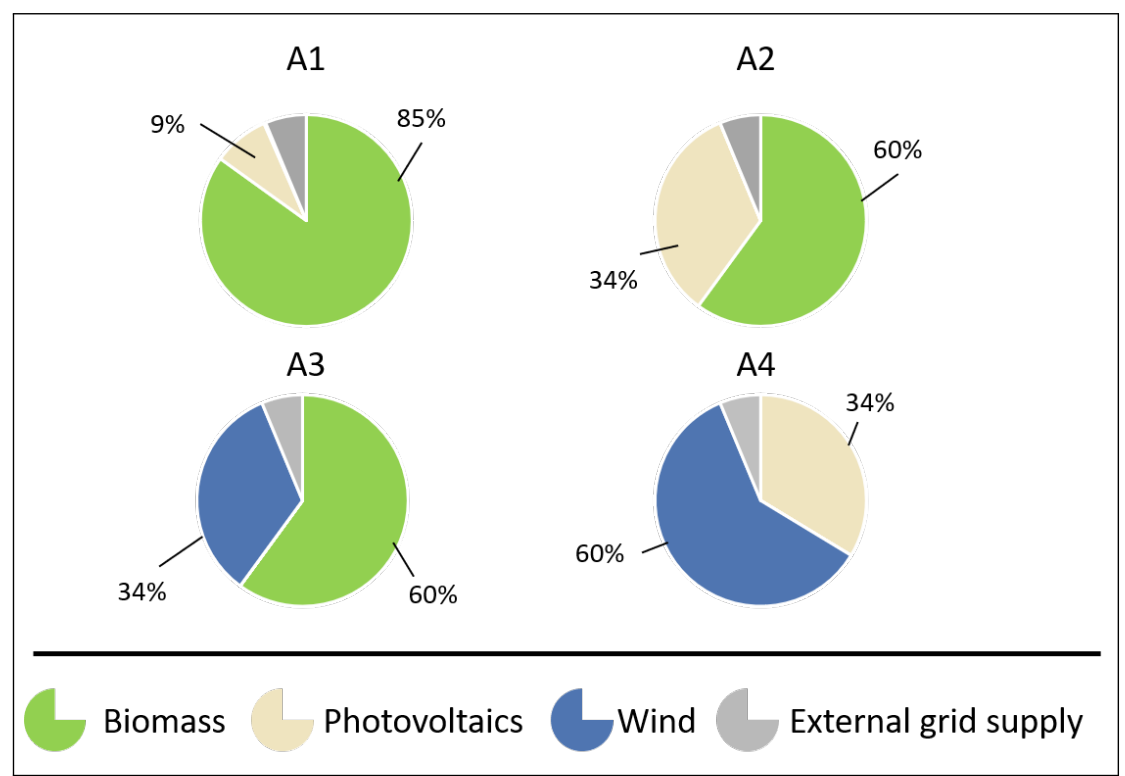

Figure 2. Alternative energy scenarios for self-sufficient electricity supply of a bioenergy village in Germany. Solar power, wind power and biomass fermentation can be utilised for the supply of electricity. The depicted scenarios represent the final states of the villages' energy system at the end of a 20-year transition process. While each alternative proposes a different utilisation of electricity from renewable sources, reliance on grid supply is required only at peak load times for up to $6 \%$ of total annual demand.

\section{Status quo alternative (A1):}

This alternative depicts the village's currently planned energy system. This scenario is included in the analysis in order to check whether altering the village's energy scenario would be at all beneficial. In this transition path's final state, biomass fermentation with additional photovoltaic systems will provide electricity. The remaining share of electricity supply is provided externally by the grid.

Biomass and photovoltaics (A2):

This path focuses on providing electricity from biomass, which amounts to $60 \%$ 
of the total electricity production. Rooftop photovoltaic systems cover $34 \%$ of the demand, while the grid provides the remaining $6 \%$ of the total demand.

\section{Biomass and wind turbine (A3):}

This energy scenario introduces generating electricity by means of wind turbines. This scenario's setup is quite similar to A2 but with electricity from a wind turbine replacing the share of electricity from solar energy.

\section{Wind turbine and photovoltaics (A4):}

In this path, biomass is not used and wind energy replaces the share of biomass in A2 and A3 (accounting for $60 \%$ of the village's total electricity supply), while rooftop photovoltaic systems (34\%) and the grid (6\%) provide the remaining energy from renewable sources.

Step 2: Stakeholder analysis

Now that the alternatives have been defined, the stakeholders need to be identified and characterised. In our case study, we consider hypothetical village inhabitants and a group of experts and academics to be stakeholders. The village inhabitants are split into three demographic age groups, namely those who are 29 or younger, those between 30 and 50 years of age and those inhabitants older than 51 in order to testify the algorithm. We chose this group configuration, since we regard the inhabitants' diverging goals and criteria as closely tied to their age. However, this does not necessarily imply that the relevant groups are fully homogeneous or that there are no intersecting opinions between them. We include the expert and academic group to foster mutual learning for all stakeholders by integrating the local inhabitants' interests, values and beliefs with the technical experts knowledge through consulting and exchanging of information, as [61-64] advise.

Step 3: Determination of criteria and weights

The criteria and the stakeholder groups' respective weightings are illustrated in Figure 3 and reflect their slightly diverging interests. While some criteria are universal across all stakeholder groups, some of the criteria are either exclusive to a certain group or of different importance.
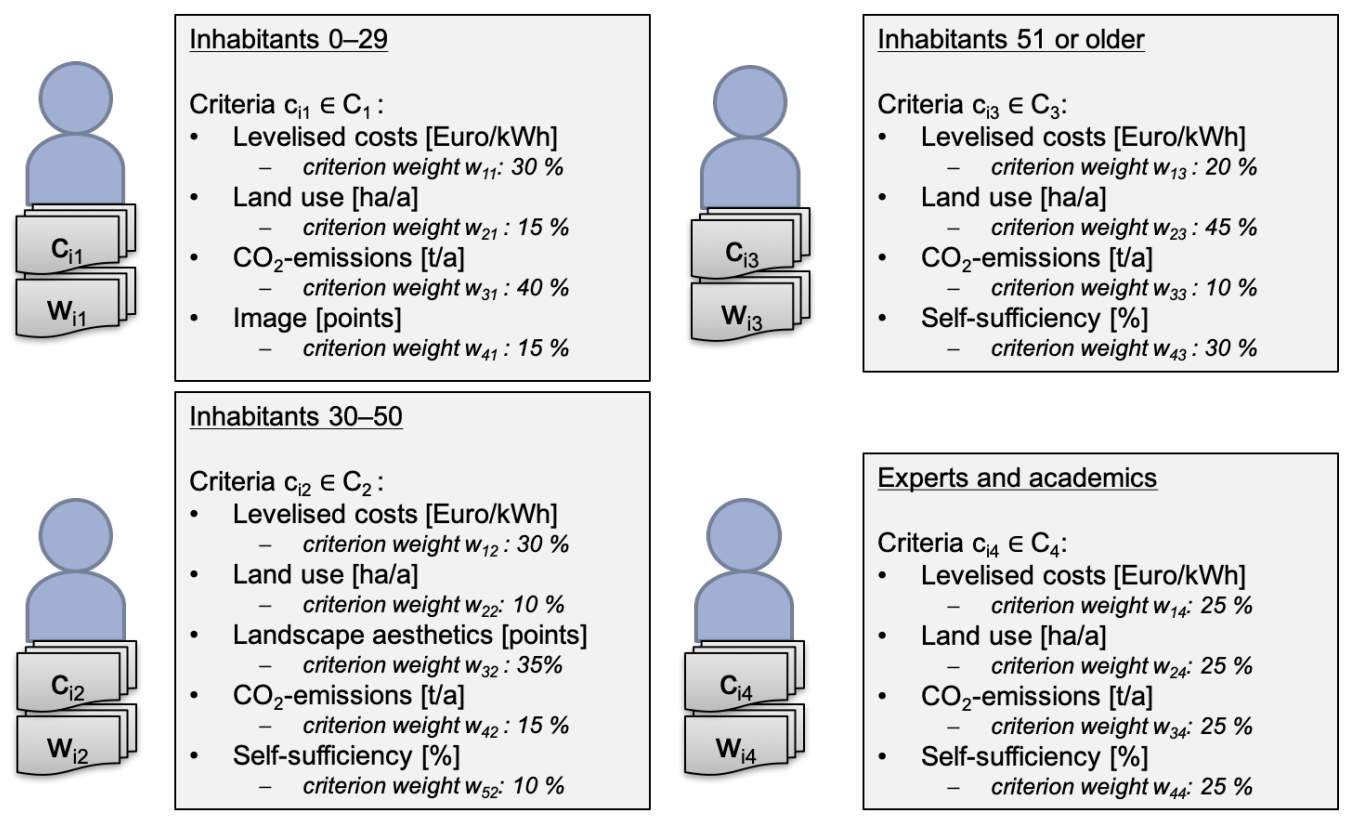

Figure 3. Criteria and criteria weights for the different stakeholder groups, which are being determined in the third step of the MAMCA method. Stakeholder groups are the village inhabitants, which are split into three demographic age groups, as well as a group of experts and academics. Each stakeholder group is granted a separate set of criteria and criteria weights to account for diverging objectives. 
The overall set of criteria assesses the alternatives with regard to their environmental, economic, social and technical aspects, finding that they are adequate [65]. The criteria are defined and measured as follows:

\section{Levelised costs of electricity (LCOE)}

reflect the average cost per unit of electricity generated. These costs are measured in Euro per kilowatt and hour [Euro/kWh].

\section{Land-use}

is measured in hectare of covered area in the village per year [ha/a]. This is the area that the power generation system covers and for biomass cultivation [66].

\section{$\mathrm{CO}_{2}$-emissions}

are only considered in respect of the share of electricity drawn from the grid. These emissions are measured in tons per year $[t / a]$.

Degree of self-sufficiency

measures the share of electricity the village is able to draw from renewable sources as a percentage of the total electricity demand across the transition process.

\section{Landscape aesthetics}

are measured on a point scale ranging from 1 to 10 . Higher scores represent more attractive aesthetics, while lower scores represent rather unattractive visual perceptions of the employed technologies.

Image refers to the perceived social acceptance of the energy technologies to be utilised [67] and is measured on a point scale ranging from 1 to 10 . Higher scores indicate that a group of stakeholders links the employed technologies with a higher social acceptance and vice versa for lower scores.

Step 4: Determination of performance scores

The performance scores are averaged over the transition period of 20 years and determined as follows:

The calculation of the levelised costs of renewable technologies is based on the studies by Nestle and Wissel et al. $[68,69]$. The levelised costs of electricity drawn from the grid are calculated by using the values provided by the German Association of Energy and Water Industries [70] and supplemented by the information from the Federal Statistical Office of Germany [71].

Regarding the land use, we assume that photovoltaic-rooftop systems do not occupy any space. The other energy technologies' specific land requirements are taken from [66]. The highest land use is required in scenario A1, in which the cultivation of crops for the biomass plant occupies larger surface area than in the other scenarios (494.95 ha/a). Consequently, the scenario that does not consider electricity from biomass (A4) occupies the least surface area.

The $\mathrm{CO}_{2}$-emissions due to the power drawn from the grid are derived from [72], while energy from renewable sources is considered carbon neutral. A linear regression was performed based on the power grid $\mathrm{CO}_{2}$-emissions between 1990 and 2017 from [72] to estimate those during the entire transition period in the presented case study.

Owing to solar and wind energy's volatile nature, the village's electricity demand is sometimes not matched or even surpassed. Using standard load profiles (SLP) for households and agricultural holdings [73], we extrapolated the village's annual energy demand. The resulting hourly demand was compared to the amount of electricity from renewable sources fed into the local distribution network [74] and used to calculate the degree of self-sufficiency. When demand cannot be fully met, additional electricity is purchased from the grid, but when there is an oversupply, the surplus electricity is fed back into the grid. Accordingly, self-sufficiency is highest in scenarios where a biomass plant is employed. Without a biomass plant, which is able to offset the variability of the more volatile energy provision from wind and photovoltaics, the lowest percentage of self-sufficiency is reached $(13 \%)$, as seen in scenario A4. 
Regarding the qualitative criteria image and landscape aesthetics, and given this case study's illustrative purpose, we assigned exemplary scores. For the complete performance matrix and each of the actors' scores, see Table 1.

Table 1. Performance matrix for all stakeholders based on their respective criteria. Accordingly, only the criteria to be considered vary between stakeholder groups, while the actual performance of an alternative regarding a criterion does not vary between stakeholder groups.

\begin{tabular}{|c|c|c|c|c|c|c|}
\hline Stakeholder & Criteria & Unit & $\begin{array}{l}\text { A1: } \\
\text { Status } \\
\text { quo }\end{array}$ & $\begin{array}{c}\text { A2: } \\
\text { Biomass and } \\
\text { Photovoltaics }\end{array}$ & $\begin{array}{c}\text { A3: } \\
\text { Biomass and } \\
\text { Wind Turbine } \\
\end{array}$ & $\begin{array}{c}\text { A4: } \\
\text { Wind Turbine and } \\
\text { Photovoltaics } \\
\end{array}$ \\
\hline \multirow{4}{*}{$\begin{array}{l}\text { Inhabitants } \\
0-29\end{array}$} & Levelised costs of electricity & [Euro/kWh] & 0.1134 & 0.1185 & 0.1003 & 0.1117 \\
\hline & Land use & [ha/a] & 494.95 & 377.63 & 384.11 & 23.12 \\
\hline & $\mathrm{CO}_{2}$-emissions & {$[\mathrm{t} / \mathrm{a}]$} & 1638.83 & 1952.40 & 1952.40 & 2074.78 \\
\hline & Image & [points] & 2.00 & 5.00 & 4.00 & 8.00 \\
\hline \multirow{5}{*}{$\begin{array}{l}\text { Inhabitants } \\
30-50\end{array}$} & Levelised costs of electricity & [Euro/kWh] & 0.1134 & 0.1185 & 0.1003 & 0.1117 \\
\hline & Land use & [ha/a] & 494.95 & 377.63 & 384.11 & 23.12 \\
\hline & Landscape aesthetics & [points] & 7.00 & 8.00 & 4.00 & 1.00 \\
\hline & $\mathrm{CO}_{2}$-emissions & {$[\mathrm{t} / \mathrm{a}]$} & 1638.83 & 1952.40 & 1952.40 & 2074.78 \\
\hline & Self-sufficiency & {$[\%]$} & 19 & 17 & 18 & 13 \\
\hline \multirow{4}{*}{$\begin{array}{l}\text { Inhabitants } 51 \\
\text { or older }\end{array}$} & Levelised costs of electricity & [Euro/kWh] & 0.1134 & 0.1185 & 0.1003 & 0.1117 \\
\hline & Land use & [ha/a] & 494.95 & 377.63 & 384.11 & 23.12 \\
\hline & $\mathrm{CO}_{2}$-emissions & {$[\mathrm{t} / \mathrm{a}]$} & 1638.83 & 1952.40 & 1952.40 & 2074.78 \\
\hline & Self-sufficiency & {$[\%]$} & 19 & 17 & 18 & 13 \\
\hline \multirow{4}{*}{$\begin{array}{l}\text { Experts and } \\
\text { academics }\end{array}$} & Levelised costs of electricity & [Euro/kWh] & 0.1134 & 0.1185 & 0.1003 & 0.1117 \\
\hline & Land use & [ha/a] & 494.95 & 377.63 & 384.11 & 23.12 \\
\hline & $\mathrm{CO}_{2}$-emissions & {$[\mathrm{t} / \mathrm{a}]$} & 1638.83 & 1952.40 & 1952.40 & 2074.78 \\
\hline & Self-sufficiency & {$[\%]$} & 18.67 & 16.79 & 17.57 & 13.08 \\
\hline
\end{tabular}

Step 5: Aggregation and ranking

We chose PROMETHEE for this case study to aggregate the scores and determine the alternatives' ranking within the different stakeholder groups, as described in Section 3.

To model the stakeholders' preferences according to PROMETHEE, we assigned, as shown in Table 2, one of the six generic types of preference functions that PROMETHEE provides [75] to each criterion. With respect to the quantitative criteria, we chose the Type III linear preference function, in which the preference increases linearly until the deviation in the performance scores between two alternatives equals the strict preference threshold. The preferences regarding the qualitative criteria image and landscape aesthetics were modelled using the Type II preference function, in which the preference only prevails if the deviation in the performance scores surpasses the indifference threshold $q$. For a further description of the six types of preference functions available in PROMETHEE, see Table A1. For illustrative purposes, the preference modelling in this case study universally applies for all stakeholders, whereas for practical applications, a separate determination for each stakeholder might be advisable.

We follow [76] when calculating the preference thresholds and estimated $p_{i l}$ as the maximum difference between performance scores of all alternatives for each criterion and $q_{i l}$ as $20 \%$ of this value.

Aggregating the data according to PROMETHEE yields numerical results as shown in Table 3 as a basis for the calculation of the MAMCA overall flows. Since the crucial part in the MAMCA methodology, just as in other multicriteria decision support methods, is not the generation of hard numerical values but to provide the decision maker with useful information to derive an informed decision, further processing and evaluation of these outranking flows is required. 
Table 2. Preference modelling for the criteria considered in this case study. The outranking method PROMETHEE provides six different types of preference functions to model the intracriterial preferences of a stakeholder. Depending on the chosen type of preference function, the according preference parameters were calculated for this case study.

\begin{tabular}{ccccc}
\hline Criteria & Orientation & Unit & Preference Function & Preference Parameters \\
\hline Levelised costs of electricity & Min & [Euro $/ \mathrm{kWh}]$ & Type III: Linear & $p_{i l}=0.0812$ \\
Land use & Min & [ha $/ \mathrm{a}]$ & Type III: Linear & $p_{i l}=471.83$ \\
$\mathrm{CO}_{2}$-emissions & $\operatorname{Min}$ & [t/a] & Type III: Linear & $p_{i l}=435.95$ \\
Self-sufficiency & $\operatorname{Max}$ & [\%] & Type III: Linear & $p_{i l}=6$ \\
Image & $\operatorname{Max}$ & [points] & Type II: Quasi & $p_{i l}=6, q_{i l}=1.2$ \\
Landscape aesthetics & Max & [points] & Type II: Quasi & $p_{i l}=6, q_{i l}=1.2$ \\
\hline
\end{tabular}

Table 3. Assessment of alternatives for the different stakeholders according to PROMETHEE as a basis for the calculation of MAMCA overall flows.

\begin{tabular}{llcccc}
\hline & & Alternative $\boldsymbol{a}_{j}$ & & \\
\hline Stakeholder Group $s_{l}$ & PROMETHEE Flows & $\begin{array}{c}\text { A1: } \\
\text { Status } \\
\text { quo }\end{array}$ & $\begin{array}{c}\text { A2: } \\
\text { Biomass and } \\
\text { Photovoltaics }\end{array}$ & $\begin{array}{c}\text { A3: } \\
\text { Biomass and } \\
\text { Wind Turbine }\end{array}$ & $\begin{array}{c}\text { A4: } \\
\text { Wind Turbine and } \\
\text { Photovoltaics }\end{array}$ \\
\hline Inhabitants 0-29 & $\phi_{1}^{+}\left(a_{j}\right)$ & 0.3532 & 0.1005 & 0.3379 & 0.3225 \\
& $\phi_{1}^{-}\left(a_{j}\right)$ & 0.3055 & 0.3489 & 0.1848 & 0.2708 \\
& $\phi_{1}^{\text {net }}\left(a_{j}\right)$ & 0.04767 & -0.2483 & 0.1489 & 0.05170 \\
\hline Inhabitants 30-50 & $\phi_{2}^{+}\left(a_{j}\right)$ & 0.43328 & 0.2783 & 0.4065 & 0.1306 \\
& $\phi_{2}^{-}\left(a_{j}\right)$ & 0.13077 & 0.2431 & 0.3008 & 0.5740 \\
& $\phi_{2}^{\text {net }}\left(a_{j}\right)$ & 0.3025 & 0.0353 & 0.1057 & -0.4435 \\
\hline Inhabitants 51 or older & $\phi_{3}^{+}\left(a_{j}\right)$ & 0.2500 & 0.1154 & 0.3010 & 0.4086 \\
& $\phi_{3}^{-}\left(a_{j}\right)$ & 0.2767 & 0.2969 & 0.1575 & 0.3438 \\
& $\phi_{3}^{\text {net }}\left(a_{j}\right)$ & -0.0268 & -0.1816 & 0.1435 & 0.0648 \\
\hline Experts and academics & $\phi_{4}^{+}\left(a_{j}\right)$ & 0.3516 & 0.1008 & 0.3218 & 0.1387 \\
& $\phi_{4}^{-}\left(a_{j}\right)$ & 0.1914 & 0.3020 & 0.1831 & -0.1420 \\
\hline
\end{tabular}

Steps 6 and 7: Evaluation, sensitivity analysis and implementation

The numerical results and the resulting MAMCA overall flows are depicted in Figure 4 to engage an extensive evaluation. Across all the stakeholders, scenario A3, which utilises a biomass plant in conjunction with wind turbines, performs best, closely followed by the status quo alternative (A1). The combined supply of electricity from biomass and from photovoltaics (A2) performs worst across all the stakeholders, except for the group of inhabitants between 30 and 50. This stakeholder group rates wind turbines and photovoltaic systems' deployment (A4) noticeably worse than the other groups, given a PROMETHEE net flow of -0.4435 . Using PROMETHEE's unicriterion net flows, we conducted an intrastakeholder analysis to examine the reasons for this negative assessment. Figure 5 depicts this intrastakeholder ranking of the group of 30 to 50-year-old inhabitants' alternatives and reveals how each alternative performs in terms of this group's criteria set. It is clear that the use of wind power and solar panels is evaluated remarkably negatively in terms of the criterion landscape aesthetics, therefore possibly requiring a sensitivity analysis of this criterion's weights. On the other hand, this knowledge is also a valuable starting point for the communication process with this group of inhabitants and allows the design and implementation of measures that specifically address the landscape aesthetics. The configuration of energy scenario A4 could also be slightly modified or another iteration of the analysis could be undertaken. 


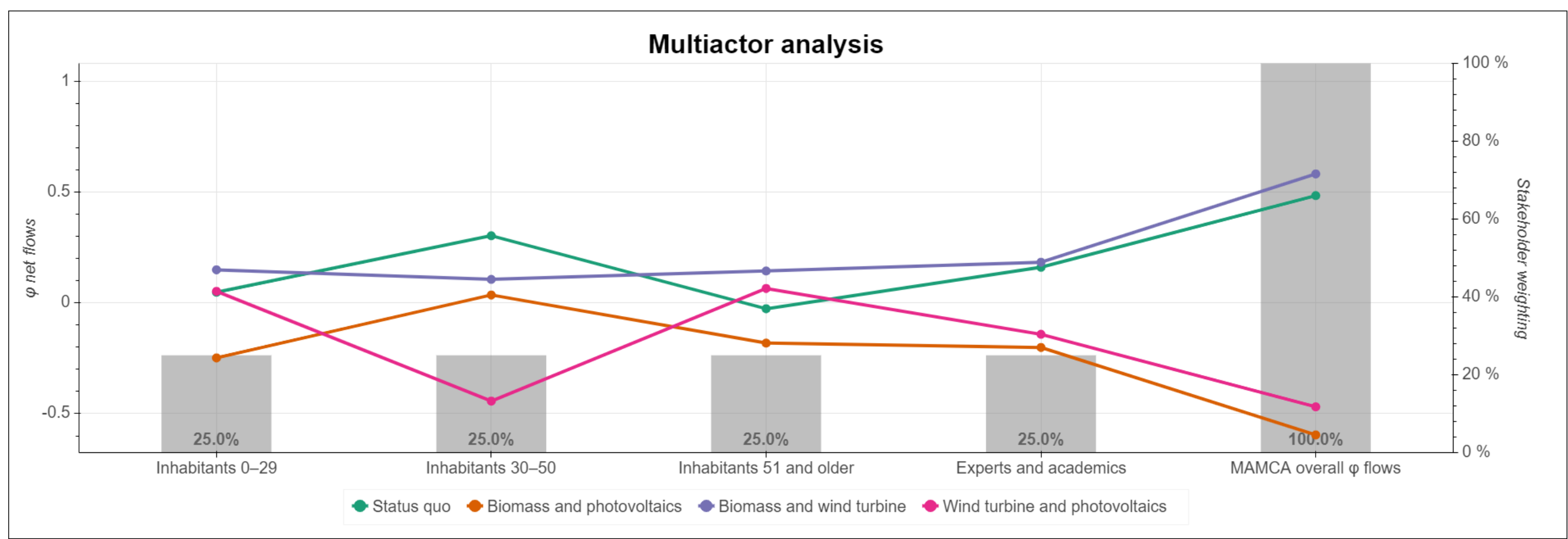

Figure 4. Multiactor view after assessment and aggregation according to PROMETHEE. 


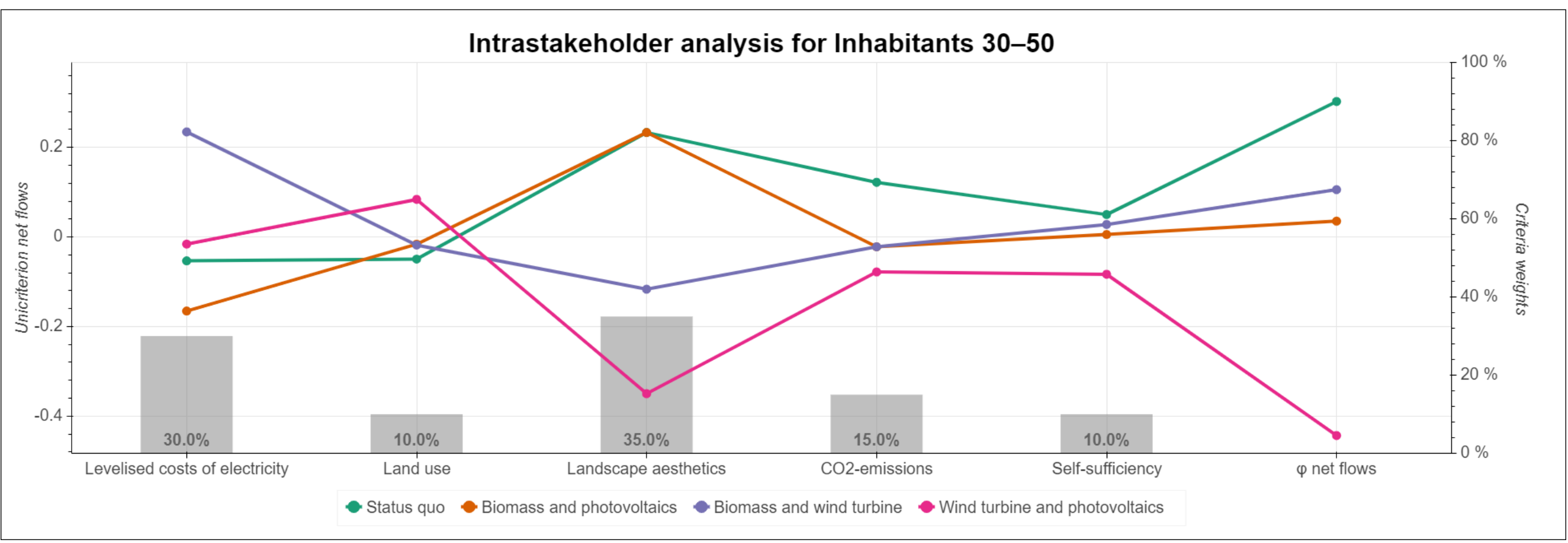

Figure 5. Intrastakeholder analysis view for the stakeholder group 30-50 years. 


\section{Conclusions}

Multicriteria analysis methods may support the assessment of options and pathways towards sustainable energy systems by providing a comprehensive evaluation of these options and possible scenarios. The methods of MCA explicitly allow for conflicting criteria within the assessment of energy scenarios but without taking multiple stakeholder objectives simultaneously into account.

Previous studies on the assessment of pathways towards sustainable energy systems addressed the issue of path dependencies, which arises when evaluating transition processes in energy systems, but they explicitly did not involve stakeholders in the assessment [3]. Therefore, we presented and applied the MAMCA methodology by Macharis et al. [13] for stakeholders' explicit and more participatory involvement in energy scenario assessment. By explicitly including a separate set of criteria for each stakeholder, the MAMCA method adds an additional layer to the available MCA methods. This not only enables decision makers to consider diverging stakeholder objectives but also to reveal the alternatives' strengths and weaknesses across multiple stakeholders. This may facilitate the process of reaching consensus between all stakeholders and foster a decision's acceptance. As shown, the methodology enables managers and policymakers in energy projects to involve stakeholders throughout the entire decision making process from the onset, which may reduce the risk of opposition upon realisation, since stakeholders are offered sufficient opportunity to express their objectives and concerns. It therefore could be of great value in future energy system projects or comparable infrastructure projects.

We showed that the MAMCA method could help researchers and decision makers in the assessment of pathways towards sustainable energy systems with multiple stakeholders by revealing each stakeholders' crucial trade-offs and indicating compromise options. For this, we conducted a case study to illustrate how an evaluation of energy scenarios by means of the MAMCA method could look like. We demonstrated the functionalities explicitly and used PROMETHEE as an aggregation method. Although there are some applications of the MAMCA methodology with PROMETHEE in other contexts, such as the assessment of large cities [77], we believe that this is the first application for the assessment of energy technologies and scenarios.

With regard to identifying stakeholder groups and integrating stakeholder views, the methods of marketing, psychology and sociology offer further possibilities for stakeholders' characterisation and clustering [78,79], but these have not yet been applied in MAMCA to evaluate energy scenarios and bear implications for future research. Moreover, further research on sensitivity analysis's extent and form could determine the minimum modification of the criteria weightings for each stakeholder in order for all of them to reach consensus [80]. Here, the integration of mathematical optimisation methods into the MAMCA framework holds great potential [81]. Furthermore, the stakeholders' criteria weightings could be subject to uncertainties. In this regard, integrating the PROMETHEE VI module [57] into the MAMCA framework with PROMETHEE as an aggregation method could yield additional insights.

Author Contributions: Conceptualisation, S.S. and J.G.; Investigation, S.S.; Methodology, S.S. and J.G.; Project administration, J.G.; Software, S.S.; Supervision, J.G.; Validation, S.S.; Visualisation, S.S.; Writing-original draft, S.S. and J.G.; Writing-review and editing, S.S. and J.G. All authors have read and agreed to the published version of the manuscript.

Funding: This research received no external funding.

Institutional Review Board Statement: Not applicable.

Informed Consent Statement: Not applicable.

Data Availability Statement: Not applicable.

Conflicts of Interest: The authors declare no conflict of interest. The funders had no role in the design of the study; in the collection, analyses, or interpretation of data; in the writing of the manuscript, or in the decision to publish the results. 


\section{Abbreviations}

The following abbreviations are used in this manuscript:

AHP analytical hierarchy process

MAMCA multiactor multicriteria analysis

MAUT multiattribute utility theory

MADM multiattribute decision making

MCA multicriteria analysis

NIMBY not in my backyard

PROMETHEE Preference ranking organisation method for enrichment evaluation

\section{Appendix A}

Table A1. Preference functions in PROMETHEE [75].

\begin{tabular}{ll}
\hline Preference Function & Definition \\
\hline \multirow{2}{*}{$\uparrow$} & Type I: Usual criterion \\
& $P(d)= \begin{cases}0 & d \leq 0 \\
1 & d>0\end{cases}$
\end{tabular}

Type II: Quasi-criterion

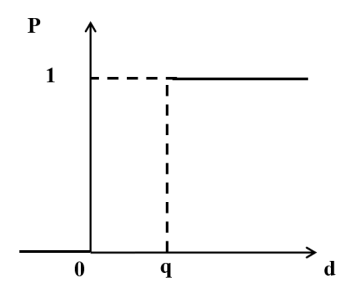

$$
P(d)= \begin{cases}0 & d \leq q \\ 1 & d>q\end{cases}
$$

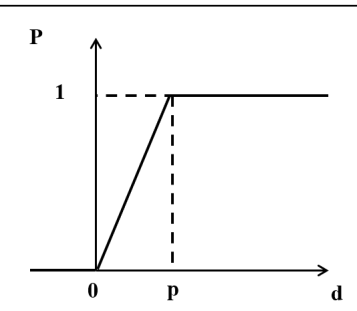

Type III: Criterion with linear preference

$$
P(d)= \begin{cases}0 & d \leq 0 \\ \frac{d}{p} & 0<d \leq p \\ 1 & d>p\end{cases}
$$

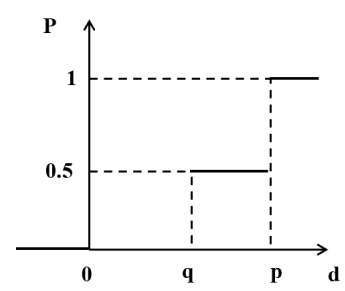

Type IV: Level criterion

$$
P(d)= \begin{cases}0 & d \leq q \\ \frac{1}{2} & q<d \leq p \\ 1 & d>p\end{cases}
$$

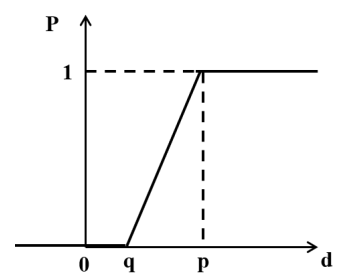

Type V: Criterion with linear preference and indifference area

$$
P(d)= \begin{cases}0 & d \leq q \\ \frac{d-q}{p-q} & q<d \leq p \\ 1 & d>p\end{cases}
$$


Table A1. Cont.

\begin{tabular}{ll}
\hline Preference Function & Definition \\
\hline$P$ & Type VI: Gaussian criterion \\
& $P(d)=\left\{\begin{array}{lll}0 & d \leq 0 \\
1-e^{-\frac{d^{2}}{2 \sigma^{2}}} & d>0\end{array}\right.$ \\
\hline
\end{tabular}

\section{References}

1. Wassermann, S.; Reeg, M.; Nienhaus, K. Current challenges of Germany's energy transition project and competing strategies of challengers and incumbents: The case of direct marketing of electricity from renewable energy sources. Energy Policy 2015, 76, 66-75. [CrossRef]

2. Bruns, E.; Futterlieb, M.; Ohlhorst, D.; Wenzel, B. Netze als Rückgrat der Energiewende; Universitätsverlag der TU Berlin: Berlin, Germany, 2012. [CrossRef]

3. Witt, T.; Dumeier, M.; Geldermann, J. Multi-criteria Evaluation of the Transition of Power Generation Systems. In Multikriterielle Optimierung und Entscheidungsunterstützung; Küfer, K.H., Ruzika, S., Halffmann, P., Eds.; Springer Fachmedien Wiesbaden: Wiesbaden, Germany, 2019; pp. 121-141.

4. Möst, D.; Fichtner, W. Einführung zur Energiesystemanalyse. In Energiesystemanalyse; Möst, D., Fichtner, W., Grunwald, A., Eds.; Univ.-verl.: Karlsruhe, Germany, 2009; pp. 11-32.

5. Grunwald, A.; Dieckhoff, C.; Fischedick, M.; Höffler, F.; Mayer, C.; Weimer-Jehle, W. Consulting with energy scenarios: Requirements for scientific policy advice. In Monograph Series on Science-Based Policy Advice, Acatech; Deutsche Akademie der Technikwissenschaften e.V.: München, Germany, 2016.

6. Hentschel, M.; Ketter, W.; Collins, J. Renewable energy cooperatives: Facilitating the energy transition at the Port of Rotterdam. Energy Policy 2018, 121, 61-69. [CrossRef]

7. Uhlemair, H.; Karschin, I.; Geldermann, J. Optimizing the production and distribution system of bioenergy villages. Int. J. Prod. Econ. 2014, 147, 62-72. [CrossRef]

8. Höfer, T.; Madlener, R. A participatory stakeholder process for evaluating sustainable energy transition scenarios. Energy Policy 2020, 139, 111277. [CrossRef]

9. Kowalski, K.; Stagl, S.; Madlener, R.; Omann, I. Sustainable energy futures: Methodological challenges in combining scenarios and participatory multi-criteria analysis. Eur. J. Oper. Res. 2009, 197, 1063-1074. [CrossRef]

10. Volkart, K.; Weidmann, N.; Bauer, C.; Hirschberg, S. Multi-criteria decision analysis of energy system transformation pathways: A case study for Switzerland. Energy Policy 2017, 106, 155-168. [CrossRef]

11. Bertsch, V.; Fichtner, W. A participatory multi-criteria approach for power generation and transmission planning. Ann. Oper. Res. 2016, 245, 177-207. [CrossRef]

12. Hauff, J.; Heider, C.; Arms, H.; Gerber, J.; Schilling, M. Public acceptance as a mainstay of energy policy planning; Gesellschaftliche Akzeptanz als Saeule der energiepolitischen Zielsetzung. Energiewirtschaftliche Tagesfragen 2011, 61, 85.

13. Macharis, C. A Methodology to Evaluate Potential Locations for Intermodal Barge Terminals: A Policy Decision Support Tool. In Transport Developments and Innovations in an Evolving World; Beuthe, M., Himanen, V., Reggiani, A., Zamparini, L., Eds.; Advances in Spatial Science; Springer: Berlin/Heidelberg, Germany, 2004; pp. 211-234. [CrossRef]

14. French, S.; Geldermann, J. The varied contexts of environmental decision problems and their implications for decision support. Environ. Sci. Policy 2005, 8, 378-391. [CrossRef]

15. Van der Horst, D. NIMBY or not? Exploring the relevance of location and the politics of voiced opinions in renewable energy siting controversies. Energy Policy 2007, 35, 2705-2714. [CrossRef]

16. Bell, D.; Gray, T.; Haggett, C. The 'Social Gap' in Wind Farm Siting Decisions: Explanations and Policy Responses. Environ. Politics 2005, 14, 460-477. [CrossRef]

17. Jobert, A.; Laborgne, P.; Mimler, S. Local acceptance of wind energy: Factors of success identified in French and German case studies. Energy Policy 2007, 35, 2751-2760. [CrossRef]

18. Guo, Y.; Ru, P.; Su, J.; Anadon, L.D. Not in my backyard, but not far away from me: Local acceptance of wind power in China. Energy 2015, 82, 722-733. [CrossRef]

19. Gonyo, S.B.; Fleming, C.S.; Freitag, A.; Goedeke, T.L. Resident perceptions of local offshore wind energy development: Modeling efforts to improve participatory processes. Energy Policy 2021, 149, 112068. [CrossRef]

20. Read, D.L.; Brown, R.F.; Thorsteinsson, E.B.; Morgan, M.; Price, I. The theory of planned behaviour as a model for predicting public opposition to wind farm developments. J. Environ. Psychol. 2013, 36, 70-76. [CrossRef]

21. Krohn, S.; Damborg, S. On public attitudes towards wind power. Renew. Energy 1999, 16, 954-960. [CrossRef] 
22. Wolsink, M. Wind power and the NIMBY-myth: institutional capacity and the limited significance of public support. Renew. Energy 2000, 21, 49-64. [CrossRef]

23. Wolsink, M. Invalid theory impedes our understanding: a critique on the persistence of the language of NIMBY. Trans. Inst. Br. Geogr. 2006, 31, 85-91. [CrossRef]

24. Hubbard, P. NIMBY by another name? A reply to Wolsink. Trans. Inst. Br. Geogr. 2006, 31, 92-94. [CrossRef]

25. Thayer, R.L.; Freeman, C.M. Altamont: Public perceptions of a wind energy landscape. Landsc. Urban Plan. 1987, 14, 379-398. [CrossRef]

26. Van der Loo, F.A. Mediating Windpower in The Netherlands: The Task Force Windpower Implementation; Novem: Utrecht, The Netherlands, 2001.

27. Stadelmann-Steffen, I.; Dermont, C. Acceptance through inclusion? Political and economic participation and the acceptance of local renewable energy projects in Switzerland. Energy Res. Soc. Sci. 2021, 71, 101818. [CrossRef]

28. Warren, C.R.; Lumsden, C.; O’Dowd, S.; Birnie, R.V. 'Green On Green': Public perceptions of wind power in Scotland and Ireland. J. Environ. Plan. Manag. 2005, 48, 853-875. [CrossRef]

29. Devine-Wright, P. Enhancing local distinctiveness fosters public acceptance of tidal energy: A UK case study. Energy Policy 2011, 39, 83-93. [CrossRef]

30. Michaud, K.; Carlisle, J.E.; Smith, E.R. Nimbyism vs. environmentalism in attitudes toward energy development. Environ. Politics 2008, 17, 20-39. [CrossRef]

31. Upham, P.; Shackley, S. Stakeholder opinion of a proposed 21.5 MWe biomass gasifier in Winkleigh, Devon: Implications for bioenergy planning and policy. J. Environ. Policy Plan. 2006, 8, 45-66. [CrossRef]

32. Gross, C. Community perspectives of wind energy in Australia: The application of a justice and community fairness framework to increase social acceptance. Energy Policy 2007, 35, 2727-2736. [CrossRef]

33. Pendall, R. Opposition to Housing. Urban Aff. Rev. 1999, 35, 112-136. [CrossRef]

34. Kraft, M.E.; Clary, B.B. Citizen Participation and the Nimby Syndrome: Public Response to Radioactive Waste Disposal. West. Political Q. 1991, 44, 299. [CrossRef]

35. Halliday, J.A. Wind energy: An option for the UK? IEE Proc. A Sci. Meas. Technol. 1993, 140, 53. [CrossRef]

36. Geldermann, J.; Bertsch, V.; Treitz, M.; French, S.; Papamichail, K.N.; Hämäläinen, R.P. Multi-Criteria Decision Support and Evaluation of Strategies for Nuclear Remediation Management. Omega 2009, 37, 238-251. [CrossRef]

37. Geldermann, J.; Treitz, M.; Bertsch, V.; Rentz, O. Moderated Decision Support and Countermeasure Planning for off-site Emergency Management. In Energy and Environment: Modeling and Analysis; Loulou, R., Waaub, J.P., Zaccour, G., Eds.; Springer: Heidelberg, Germany, 2005; pp. 63-80.

38. Hämäläinen, R.P.; Mustajoki, J.; Marttunen, M. Web-Based Decision Support: Creating a Culture of Applying Multi-criteria Decision Analysis and Web-Supported Participation in Environmental Decision Making. In e-Democracy; Rios Insua, D., French, S., Eds.; Advances in Group Decision and Negotiation; Springer: Berlin/Heidelberg, Germany, 2010; pp. 201-221. [CrossRef]

39. Keefer, D.L.; Kirkwood, C.W.; Corner, J.L. Perspective on Decision Analysis Applications, 1990-2001. Decis. Anal. 2004, 1, 4-22. [CrossRef]

40. Stewart, T.J. A critical survey on the status of multiple criteria decision making theory and practice. Omega 1992, 20,569-586. [CrossRef]

41. Rigo, P.D.; Rediske, G.; Rosa, C.B.; Gastaldo, N.G.; Michels, L.; Neuenfeldt Júnior, A.L.; Siluk, J.C.M. Renewable Energy Problems: Exploring the Methods to Support the Decision-Making Process. Sustainability 2020, 12, 10195. [CrossRef]

42. Siksnelyte-Butkiene, I.; Zavadskas, E.K.; Streimikiene, D. Multi-Criteria Decision-Making (MCDM) for the Assessment of Renewable Energy Technologies in a Household: A Review. Energies 2020, 13, 1164. [CrossRef]

43. Marttunen, M.; Mustajoki, J.; Dufva, M.; Karjalainen, T.P. How to design and realize participation of stakeholders in MCDA processes? A framework for selecting an appropriate approach. EURO J. Decis. Process. 2015, 3, 187-214. [CrossRef]

44. Stirling, A. Analysis, participation and power: Justification and closure in participatory multi-criteria analysis. Land Use Policy 2006, 23, 95-107. [CrossRef]

45. Munda, G. Social multi-criteria evaluation: Methodological foundations and operational consequences. Eur. J. Oper. Res. 2004, 158, 662-677. [CrossRef]

46. Huang, I.B.; Keisler, J.; Linkov, I. Multi-criteria decision analysis in environmental sciences: ten years of applications and trends. Sci. Total. Environ. 2011, 409, 3578-3594. [CrossRef] [PubMed]

47. Keeney, R.L. Value-Focused Thinking: A Path to Creative Decision Making; Harvard University Press: Cambridge, MA, USA, 1996.

48. Steinhilber, S.; Geldermann, J.; Wietschel, M. Renewables in the EU after 2020: a multi-criteria decision analysis in the context of the policy formation process. EURO J. Decis. Process. 2016, 4, 119-155. [CrossRef]

49. Macharis, C.; de Witte, A.; Ampe, J. The multi-actor, multi-criteria analysis methodology (MAMCA) for the evaluation of transport projects: Theory and practice. J. Adv. Transp. 2009, 43, 183-202. [CrossRef]

50. Belton, V.; Stewart, T. Multiple Criteria Decision Analysis-An Integrated Approach; Kluwer Academic Publishers: Boston, MA, USA, 2002.

51. Macharis, C.; Bernardini, A. Reviewing the use of Multi-Criteria Decision Analysis for the evaluation of transport projects: Time for a multi-actor approach. Transp. Policy 2015, 37, 177-186. [CrossRef] 
52. Zardari, N.H.; Ahmed, K.; Shirazi, S.M.; Yusop, Z.B. Weighting Methods and Their Effects on Multi-Criteria Decision Making Model Outcomes in Water Resources Management; Springer International Publishing: Cham, Switzerland, 2015. [CrossRef]

53. Goodwin, P.; Wright, G. Decision Analysis for Management Judgment, 5th ed.; Wiley: Chichester, UK, 2014.

54. Brans, J.P.; Vincke, P.; Mareschal, B. How to select and how to rank projects: The Promethee method. Eur. J. Oper. Res. 1986, 24, 228-238. [CrossRef]

55. Saaty, T.L. How to make a decision: The Analytic Hirarchy Process. Eur. J. Oper. Res. 1991, 48, 9-26. [CrossRef]

56. Roy, B. The Outranking Approach and the Foundations of Electre Methods. In Readings in Multiple Criteria Decision Aid; Bana, E., Costa, C.A., Ed.; Springer: Berlin/Heidelberg, Germany, 1990; pp. 155-183. [CrossRef]

57. Brans, J.P.; de Smet, Y. PROMETHEE Methods. In Multiple Criteria Decision Analysis; Greco, S., Ehrgott, M., Figueira, J., Eds.; International Series in Operations Research \& Management Science; Springer: New York, NY, USA, 2016; pp. 187-219. [CrossRef]

58. Hadavi, S.; Macharis, C.; van Raemdonck, K. The Multi-Actor Multi-Criteria Analysis (MAMCA) Tool: Methodological Adaptations and Visualizations. In Advanced Concepts, Methodologies and Technologies for Transportation and Logistics; Żak, J., Hadas, Y., Rossi, R., Eds.; Advances in Intelligent Systems and Computing; Springer International Publishing: Cham, Switzerland, 2018; Volume 572, pp. 39-53. [CrossRef]

59. Behzadian, M.; Kazemzadeh, R.B.; Albadvi, A.; Aghdasi, M. PROMETHEE: A comprehensive literature review on methodologies and applications. Eur. J. Oper. Res. 2010, 200, 198-215. [CrossRef]

60. Oberschmidt, J.; Geldermann, J.; Ludwig, J.; Schmehl, M. Modified PROMETHEE approach for assessing energy technologies. Int. J. Energy Sect. Manag. 2010, 4, 183-212. [CrossRef]

61. Trutnevyte, E.; Stauffacher, M.; Scholz, R.W. Supporting energy initiatives in small communities by linking visions with energy scenarios and multi-criteria assessment. Energy Policy 2011, 39, 7884-7895. [CrossRef]

62. Scholz, R.W.; Mieg, H.A.; Oswald, J.E. Transdisciplinarity in groundwater management-Towards mutual learning of science and society. Water Air Soil Pollut. 2000, 123, 477-487. [CrossRef]

63. Scholz, R.W.; Lang, D.J.; Wiek, A.; Walter, A.I.; Stauffacher, M. Transdisciplinary case studies as a means of sustainability learning. Int. J. Sustain. High. Educ. 2006, 7, 226-251. [CrossRef]

64. Stauffacher, M.; Flüeler, T.; Krütli, P.; Scholz, R.W. Analytic and Dynamic Approach to Collaboration: A Transdisciplinary Case Study on Sustainable Landscape Development in a Swiss Prealpine Region. Syst. Pract. Action Res. 2008, 21, 409-422. [CrossRef]

65. Lerche, N.; Wilkens, I.; Schmehl, M.; Eigner-Thiel, S.; Geldermann, J. Using methods of Multi-Criteria Decision Making to provide decision support concerning local bioenergy projects. Socio Econ. Plan. Sci. 2017. [CrossRef]

66. Genske, D.; Jödecke, T.; Ruff, A.; Porsche, L. Nutzung Städtischer Freiflächen für Erneuerbare Energien: Ein Projekt des Forschungsprogramms "Experimenteller Wohnungs- und Städtebau" (ExWoSt) des Bundesministeriums für Verkehr, Bau und Stadtentwicklung (BMVBS) und des Bundesamtes für Bauwesen und Raumordnung (BBR); Bundesamt für Bauwesen und Raumordnung: Bonn, Germany, 2009.

67. Wüstenhagen, R.; Wolsink, M.; Bürer, M.J. Social acceptance of renewable energy innovation: An introduction to the concept. Energy Policy 2007, 35, 2683-2691. [CrossRef]

68. Nestle, U.; Kunz, C. Studienvergleich: Stromgestehungskosten Verschiedener Erzeugungstechnologien; Forschungsradar EnergiewendeMetaanalyse: Berlin, Germany, 2014.

69. Wissel, S.; Rath-Nagel, M.; Blesl, U.; Fahl, U.; Voß, A. Stromerzeugungskosten im Vergleich; IER: Stuttgart, Germany, 2008.

70. Bundesverband der Energie- und Wasserwirtschaft e.V. BDEW-Strompreisanalyse Mai 2018; Bundesverband der Energie- und Wasserwirtschaft e.V.: Berlin, Germany, 2018.

71. Statistisches Bundesamt. Index der Erzeugerpreise Gewerblicher Produkte (Inlandsabsatz) nach dem Güterverzeichnis für Produktionsstatistiken: Lange Reihen der Fachserie 17, Reihe 2 von Januar 2000 bis Juni 2018; Statistisches Bundesamt: Wiesbaden, Germany, 2018.

72. Icha, P. Entwicklung der spezifischen Kohlendioxid-Emissionen des deutschen Strommix in den Jahren 1990-2016. Clim. Chang. 2017, 15, 2017.

73. ED Netze GmbH. Lastprofile der ED Netze GmbH, 27.10.2017; ED Netze GmbH: Rheinfelden, Germany, 2017.

74. 50Hertz Transmission GmbH. Zeitlicher Verlauf der EEG-Stromeinspeisung; 50Hertz Transmission GmbH: Berlin, Germany, 2017.

75. Brans, J.P.; Vincke, P. Note-A Preference Ranking Organisation Method: The PROMETHEE Method for Multiple Criteria Decision-Making. Manag. Sci. 1985, 31, 647-656. [CrossRef]

76. Tsoutsos, T.; Drandaki, M.; Frantzeskaki, N.; Iosifidis, E.; Kiosses, I. Sustainable energy planning by using multi-criteria analysis application in the island of Crete. Energy Policy 2009, 37, 1587-1600. [CrossRef]

77. Kourtit, K.; Macharis, C.; Nijkamp, P. A multi-actor multi-criteria analysis of the performance of global cities. Appl. Geogr. 2014, 49, 24-36. [CrossRef]

78. Fortes, P.; Alvarenga, A.; Seixas, J.; Rodrigues, S. Long-term energy scenarios: Bridging the gap between socio-economic storylines and energy modeling. Technol. Forecast. Soc. Chang. 2015, 91, 161-178. [CrossRef]

79. Trutnevyte, E.; Barton, J.; O'Grady, Á.; Ogunkunle, D.; Pudjianto, D.; Robertson, E. Linking a storyline with multiple models: A cross-scale study of the UK power system transition. Technol. Forecast. Soc. Chang. 2014, 89, 26-42. [CrossRef]

80. Doan, N.; de Smet, Y. An alternative weight sensitivity analysis for PROMETHEE II rankings. Spec. Issue Mult. Criteria Decis. Mak. Eng. 2018, 80, 166-174. [CrossRef]

81. Huang, H.; de Smet, Y.; Macharis, C.; Doan, N.A.V. Collaborative decision-making in sustainable mobility: identifying possible consensuses in the multi-actor multi-criteria analysis based on inverse mixed-integer linear optimization. Int. J. Sustain. Dev. World Ecol. 2021, 28, 64-74. [CrossRef] 